\title{
Pengaruh Sumber Daya Finansial, Aset Tidak Berwujud dan Keunggulan Bersaing yang Berimplikasi Terhadap Kinerja Usaha Mikro, Kecil dan Menengah di Lombok NTB
}

\author{
The Effect of Financial Resources, Intangible Assets and Competitive Advantage \\ Which the Implicating on SMEs Performance at Lombok NTB
}

\author{
Ahmad Fauzi ${ }^{*}$, Budi Suharjo ${ }^{2 \sharp}$, dan Muhammad Syamsun ${ }^{3 \#}$ \\ ${ }^{1}$ Deputi Bidang Pengawasan Kementerian Koperasi dan UKM \\ Jalan Rasuna Said Kav.3-4 Kuningan Jakarta Selatan; Telpon/Fax : 021-29410282 \\ ${ }^{2}$ Departemen Matematika, Fakultas Matematika dan Ilmu Pengetahuan Alam, IPB \\ ${ }^{3}$ Departemen Manajemen Fakultas Ekonomi dan Manajemen, IPB \\ \#Jl. Kamper Kampus IPB Dramaga Bogor 16680
}

\begin{abstract}
ABSTRAK
Penelitian ini menganalisis sumber daya finansial, aset tidak berwujud (modal inovasi, modal manusia dan modal pelanggan), keunggulan bersaing dan kinerja keuangan, serta pengaruhnya dan menganalisis kelayakan usaha dilihat dari Net Present Value (NPV), Profitability Index (PI), Payback Period (PP) dan Internal Rate of Return (IRR) pada usaha komoditas Sapi, Jagung dan Rumput Laut (PIJAR). Metode yang digunakan pendekatan kualitatif dan kuantitatif, pemilihan responden secara purposive sampling dengan kriteria Pelaku UMKM yang bergerak pada komoditas sapi, jagung dan rumput laut di Lombok NTB. Penelitian ini menggunakan alat analisis Partial Least Square (PLS) yang merupakan metode statistika berbasis varian. Hasil penelitian menunjukkan sumber daya finansial memiliki kapasitas cukup baik $(3,29)$, aset tidak berwujud memiliki kapasitas cukup baik $(3,86)$, strategi bersaing keunggulan biaya cukup baik $(3,92)$ dan kinerja keuangan cukup baik. Hal lainnya terkait komoditas PIJAR : (1) Sumber daya finansial tidak berpengaruh terhadap kinerja keuangan dan strategi bersaing keunggulan biaya, maka kapasitas sumber daya finansial cukup baik, walau belum mampu berkontribusi terhadap kinerja keuangan; (2) Modal Inovasi berpengaruh terhadap kinerja keuangan, namun tidak berpengaruh terhadap strategi bersaing; Modal Manusia berpengaruh terhadap kinerja keuangan dan strategi bersaing; Modal Pelanggan berpengaruh terhadap kinerja keuangan dan strategi bersaing; dan (3) Kelayakan usaha komoditas PIJAR sangat baik dilihat dari NPV, PP, PI dan IRR.
\end{abstract}

Kata kunci: aset tidak berwujud, keunggulan bersaing, kinerja keuangan, sumber daya finansial

\section{ABSTRACT}

The research analyzes the financial resources, intangible assets (innovation capital, human capital, and customer capital), competitive advantage and financial performance, also analyzing its effect and analyzing business feasibility from the point view of Net Present Value (NPV), Profitability Index (PI), Payback Period (PP) and Internal Rate of Return (IRR) on cow commodities, corn and seaweed (PIJAR). The method used is qualitative and quantitative, the respondent are choose by purposive sampling with the criteria of SME which conduct their business on cow commodities, corn and seaweed at Lombok NTB Region. This research is using the Partial Least Square (PLS) analysis which is a statistical method on varian basis. The research results obtained by the Financial Resource Capacity has well sufficient capacity of (3.29), Intangible Asset have well sufficient capacity of (3.86), well good for Competitive Strategy Excellence Cost of (3.92) and quite good Financial Performance. The influence among variables on the seaweed commodities : (1) Financial Resource does not affect the financial performance and price competitive competition, so the financial resources capacity is well good, although its not yet able to contribute on the financial performance; (2) Innovation capital affect on financial performances but do not affect on competitive strategy; human capital affect on the financial performance and competitive

\footnotetext{
*) Korespondensi:

Deputi Bidang Pengawasan, Kementerian Koperasi dan UKM

Gedung Annex Lt.2 Jalan Rasuna Said Kav.3-4 Kuningan Jakarta Selatan; e-mail: fauzi876@gmail.com
} 
strategy; customer capital affect on the financial performance and competitive strategy; and (3) The business feasibility for PIJAR commodities are very well based on the view point of NPV, PP, PI and IRR.

Key words: competitive advantage, financial resources, financial performance, intangible assets

\section{PENDAHULUAN}

Peran Usaha Mikro, Kecil dan Menengah (UMKM) dalam perekonomian Indonesia sangat penting. UMKM dominan beraktifitas di lingkungan ekonomi domestik, sehingga tidak mengherankan sektor UMKM selalu tampil menjadi "pahlawan" bagi perekonomian Indonesia, ketika ekonomi nasional berhadapan dengan krisis keuangan yang juga kerap menghantam ekonomi global. Oleh sebab itu, sangat beralasan jika pemerintah dan pihak-pihak terkait mengambil posisi terdepan dalam mendorong UMKM untuk berkembang dengan lebih baik.

Berdasarkan data tahun 2014 Kementerian Koperasi dan UKM bekerjasama dengan Badan Pusat Statistik (BPS), UMKM memiliki jumlah pelaku usaha mencapai 59,26 juta unit usaha atau memiliki kontribusi sebesar 99,99\%. Menyerap tenaga kerja 123,23 juta pekerja (96,71\%). Menyumbang PDB Rp6,228 triliun (61,41\%). Serta memberikan sumbangan devisa Rp185,98 triliun $(15,73 \%)$.

UMKM di Indonesia sebagai salah satu pondasi perekonomian yang kuat masih memiliki beberapa masalah dalam perkembangannya, seperti (1) akses ke sumber finansial, baik ke lembaga keuangan baik bank maupun bukan bank, (2) kapasitas modal manusia pelaku UMKM masih tergolong rendah, (3) kemampuan inovasi produk, (4) kapasitas pemasaran dan jaringan usaha terbatas, (5) kemampuan teknologi produksi yang masih rendah, dan (6) lemahnya kemampuan manajerial dan sumber daya manusia mengakibatkan pengusaha kecil tidak mampu menjalankan usahanya dengan baik.

Strategi bisnis UMKM merupakan suatu proses yang memberikan nilai tambah dan merupakan alokasi dan koordinasi sumbersumber yang bersifat efektif. Keefektifan tersebut ditunjukkan oleh keunikan yang menimbulkan keunggulan bersaing.

Strategi harus didesain untuk mewujudkan keunggulan bersaing yang terus menerus, sehingga perusahaan dapat mendominasi pasar lama maupun pasar baru. Hal terpenting dalam mencapai kesuksesan strategi yang diterapkan adalah dengan mengidentifikasi aset perusahaan yang sesungguhnya, dalam hal ini adalah sumber daya berwujud (tangible) dan tidak berwujud (intangible) yang membuat organisasi itu unik. (Prakosa, 2005).

Kinerja UMKM diukur menggunakan tiga indikator, menurut Frazier, B. Niehm, L.S. (2008). Responden menyatakan bahwa kinerja usaha mereka secara keseluruhan dilihat dari: (1) perbandingan dengan tahun terakhir; (2) perbandingan dengan pesaing utama; dan (3) perbandingan dengan perusahaan lain dalam industri sejenis. Dukungan empiris telah ditunjukkan oleh banyak peneliti dalam penggunaan indikator kinerja keuangan perusahaan kecil (Hadjimonalis, 2000) menggunakan tingkat pertumbuhan penjualan, pertumbuhan tenaga kerja, tingkat pengembalian aset (return on asset atau ROA), profitabilitas dan ukuran market share, sebagai indikator dalam pengukuran kinerja perusahaan.

Penelitian yang berkaitan dengan faktorfaktor yang mempengaruhi kinerja UMKM telah banyak dilakukan, namun penelitian ini dalam rangka memperkuat karena adanya penambahan varibel lain. Indo Yama Nasaruddin (2014) melakukan penelitian disertasi pengaruh sumber daya keuangan dan aset tidak berwujud terhadap kinerja keuangan UMKM di Jakarta Selatan menghasilkan sumber daya finansial berpengaruh nyata terhadap kinerja keuangan namun aset tidak berwujud tidak berpengaruh secara nyata terhadap kinerja keuangan.

Undang-undang No. 22 Tahun 1999 tentang pemerintahan daerah (UUPD) menjadi salah satu landasan yang mengatur tentang pelaksanaan otonomi daerah. Kebijakan tersebut merupakan bentuk dukungan pemerintah pusat untuk daerah tingkat provinsi atau kota/kabupaten untuk mengelola rumah tangganya sendiri sesuai dengan potensi wilayahnya.

Salah satu daerah yang merasakan dampak positif dari otonomi daerah adalah Nusa Tenggara Barat (NTB). Potensi NTB tergambar dalam kekuatan sumber daya alam yang berlimpah dari sektor perikanan, pelabuhan dan pariwisata menjadi ujung tombak dalam mencapai kesejahteraan masyarakat.

Pemerintah NTB memiliki program unggulan PIJAR dalam meningkatkan taraf hidup masyarakat NTB. PIJAR merupakan kepanjangan 
dari sapi, jagung dan rumput laut yang menjadi sektor andalan NTB. Rumput laut yang dihasilkan bisa mencapai 750.000 ton setiap tahunnya, begitu juga dengan program bumi sejuta sapi karena alam yang baik untuk peternakan. Tentunya ini merupakan suatu hal yang sangat potensial dan harus mendapat dukungan pemerintah daerah sepenuhnya.

Berdasarkan pertimbangan tersebut maka penelitian terkait dengan analisis kelayakan ekonomi yang terdiri dari analisis marketing, produksi dan sumber daya manusia dan analisis finansial untuk melihat kelayakan usaha dan Analisis Pengaruh Sumber Daya Finansial dan Aset Berwujud terhadap Keunggulan bersaing serta Dampaknya terhadap Kinerja Keuangan UMKM di Lombok NTB penting untuk dilakukan.

\section{Program Unggulan Daerah Prov. NTB Berbasis Sumber Daya Lokal PIJAR (Sapi, Jagung, Rumput Laut)}

Salah satu kebijakan Pemerintah Provinsi NTB dalam mengembangkan UMKM tertuang dalam Rencana Pembangunan Jangka Menengah Daerah (RPJMD) tahun 2009 dan Peraturan Daerah Provinsi NTB tahun 2011 yaitu fokus pengembangan produk unggulan daerah dengan Program Pengembangan Bumi Sejuta Sapi, Jagung dan Rumput Laut (PIJAR).

1. Komoditas Sapi, NTB merupakan daerah sumber ternak bibit dan ternak potong naional. Setiap tahunnya NTB memberikan kontribusi sebagai penyedia bibit sapi mencapai 12 ribu ekor untuk 14 provinsi di Indonesia. Dukungan NTB terhadap Program Percepatan Swasembada Daging Sapi (P2SDS) Nasional sangat besar, mencapai 31.728 ekor pertahun.

2. Komoditas Jagung, berpotensi dari segi luas lahan untuk pengembangan jagung memiliki potensi lahan untuk pengembangannya di NTB mencapai 126.577 hektar. Potensi lahan untuk pengembangan jagung di NTB baru mencapai 129,3 Kw per hektar. Produksi jagung NTB dapat mencapai 97.171,8 ton.

3. Komoditas Rumput Laut, budidaya rumput laut dan mutiara NTB dilirik banyak pemilik modal. Potensi rumput laut, terutama jenis Eucheuma Cottoni, mencapai 22,8 ribu hektar dengan potensi produksi tiap tahunnya ditaksir bisa mencapai kurang lebih 765 ton kering. Produksi rumput laut pada 2015 mencapai 918.021 ton basah, meningkat dibandingan tahun sebelumnya sebanyak 770.374 ton. Adapun target produksi rumput laut hingga 2018 mencapai 1 juta ton dengan nilai ekonomi mencapai Rp2 triliun dengan jumlah serapan tenaga kerja 37.000 orang.

Tabel 1. Pertumbuhan komoditas Pijar

\begin{tabular}{lrrr}
\hline Komoditas & \multicolumn{1}{c}{$\mathbf{2 0 1 3}$} & \multicolumn{1}{c}{$\mathbf{2 0 1 4}$} & \multicolumn{1}{c}{$\mathbf{2 0 1 5}$} \\
\hline Sapi & 1.022 .731 & 1.013 .793 & 1.055 .013 \\
Jagung & 300.006 & 785.864 & 785.863 \\
Rumput Laut & $620.115,6$ & $749.140,5$ & $920.710,36$ \\
\hline
\end{tabular}

\section{Permasalahan Penelitian}

Berdasarkan fenomena tersebut, maka yang menjadi masalah penelitian ini diidentifikasi masih rendahnya pelaku usaha mikro yang memperoleh akses sumber pembiayaan eksternal karena mayoritas menggunakan modal sendiri, tingkat pendidikan formal masih rendah, kemampuan inovasi dan kemampuan pemasaran juga belum begitu baik. Maka penelitian mengkaji kinerja usaha mikro menarik dilakukan, mengingat semakin merosotnya daya saing Indonesia dalam persaingan global saat ini. Informasi tentang perkembangan dan kondisi usaha mikro perlu dieksplorasi untuk mendapatkan gambaran yang komprehensif. Penelitian ini memfokuskan pada usaha mikro di Lombok NTB.

Penelitian ini juga untuk mengidentifikasi gambaran mengenai aset berwujud, dengan komponen modal inovasi (innovation capital), modal manusia (human capital), dan modal pelanggan (customer capital) dan keunggulan bersaing yang dapat dirumuskan permasalahan sebagai berikut:

1. Bagaimana kapasitas sumber daya finansial, aset tidak berwujud dengan komponen modal manusia, modal inovasi, modal pelanggan, keunggulan bersaing dan kinerja keuangan pada usaha komoditas Sapi, Jagung dan Rumput Laut (PIJAR) di Lombok NTB;

2. Apakah terdapat pengaruh sumber daya finansial, aset tidak berwujud dengan komponen modal manusia, modal inovasi, modal pelanggan terhadap keunggulan bersaing dan dampaknya terhadap kinerja keuangan UMKM pada usaha komoditas olahan rumput laut di Lombok NTB;

3. Bagaimana kelayakan usaha dilihat dari net present value, profitability index, payback period dan internal rate of return pada usaha komoditas Sapi, Jagung dan Rumput Laut (PIJAR) di Lombok NTB.

Tujuan penelitian ini adalah (1) Menganalisis secara deskriptif sumber daya finansial, 
aset tidak berwujud dengan komponen modal manusia, modal inovasi, modal pelanggan, keunggulan bersaing dan kinerja keuangan pada usaha komoditas Sapi, Jagung dan Rumput Laut (PIJAR) di Lombok NTB; (2) Menganalisis pengaruh sumber daya finansial, dan aset tidak berwujud dengan komponen modal manusia, modal inovasi, modal pelanggan terhadap keunggulan bersaing dan dampaknya terhadap kinerja keuangan UMKM pada usaha komoditas rumput laut di Lombok NTB; dan (3) Menganalisis kelayakan usaha dilihat dari net present value, profitability index, payback period dan internal rate of return pada usaha komoditas Sapi, Jagung dan Rumput Laut (PIJAR) di Lombok NTB.

\section{METODE PENELITIAN}

Pendekatan yang digunakan dalam kajian ini adalah pendekatan kualitatif dan kuantitatif. Kualitatif digunakan untuk menganalisa kajian literatur yang berkenaan dengan variable-variabel yang digunakan dalam pengumpumpulan data. Kuantitatif diperoleh dari hasil penyebaran kuisioner kepada responden. Pendekatan ini dilakukan agar kajian ini memperoleh hasil yang valid dan komprehensif.

Tema utama penelitian yang dilakukan adalah mencoba melihat kapasitas sumber daya, aset tidak berwujud, strategi bersaing keunggulan biaya dan kinerja pada produk unggulan sektor peternakan sapi dan produk turunannya, budidaya jagung dan produk turunannya, dan budidaya rumput laut dan produk turunannya di Lombok NTB. Kemudian melihat pengaruh antar variabel eksogen yaitu sumber daya finansial dan aset tidak berwujud terhadap variabel endogen yaitu strategi bersaing dan dampaknya terhadap kinerja keuangan. Kemudian dilakukan uji kelayakan bisnis dengan pendekatan Net Present Value (NPV), Profitability Index (PI), Payback Periods $(P P)$ dan Internal Rate Of Return (IRR).

\section{Variabel dan Konsep Variabel}

\section{Sumber daya finansial (Financial Resource)}

Sumber modal yang berasal dari kemampuan untuk mengakses sumber keuangan berdampak pada keberhasilan mengembangkan bisnis. Storey (1994), Fisher \& Massey, 2000, Hurst \& Lusardi (2004), Camison dan Lopez (2010), Berge, Bjorvatn dan Tungodden (2011) dan ElHamidi (2011) Kapasitas memperoleh informasi pasar keuangan, Kapasitas/kemampuan untuk meningkatkan modal, Akses sumber pembiayaan dan kemampuan memperoleh sumber pembiayaan dengan biaya rendah.

\section{Aset tak berwujud (Aset Intangible)}

Aset tidak berwujud sedikit sulit untuk dipahami karena tidak nyata, sulit untuk diukur, tidak dilaporkan dalam akuntansi, harus dikembangkan setiap saat, tidak mudah diperoleh, dibeli dan ditiru secara instan. Aset berwujud penting tetapi tidak cukup untuk menjadikan keunggulan dalam bersaing karena sebagian besar aset berwujud ini dapat ditiru atau diperoleh melalui pasar. Sehingga dengan demikian apakah aset tidak berwujud dapat membuat perusahaan berbeda dalam memperoleh keberhasilan dan yang bagaimana membuat kegagalan.

Aset tidak berwujud merupakan hak, keistimewaan dan manfaat kepemilikan atau pengendalian. Dua karakteristik umum aset tidak berwujud adalah tingginya ketidakpastian masa manfaat dan tidak adanya wujud fisik. Aset tidak berwujud dapat digolongkan menjadi aset tidak berwujud yang dapat diidentifikasi (identifiable intangible asset) dan aset tidak berwujud yang tidak teridentifikasi (unidentifiable intangible asset).

Aset yang tidak nyata, sulit untuk diukur, tidak dilaporkan dalam akuntansi, harus dikembangkan setiap saat, tidak mudah diperoleh, dibeli dan ditiru secara instan. sumber daya intangible dapat berupa brand name and trademarks, reputation, patens and licences, technical or marketing know-how, trade secret and intellectual property. Mark. L. Lengnick-Hall dan Cynthia A. LengnickHall (2003), Alfred A. Marcus (2011).

1. Modal Inovasi (Innovation Capital)

2. Modal Manusia (Human Capital)

3. Modal Pelanggan (Customer Capital)

Berdasarkan konsep dari para peneliti tersebut bahwa aset tidak berwujud merupakan aset yang tidak nyata wujudnya, tidak dilaporkan dalam akuntansi namun mempunyai peran yang penting dalam perusahaan. Aset tidak berwujud perusahaan antara lain yaitu: modal manusia, berupa kemampuan dan keahlian yang dimiliki atau properti intelektual; modal inovasi yang merupakan daya kreativitas organisasi untuk menciptakan sesuatu yang bernilai; dan modal pelanggan atau pemasaran dalam menyampaian nilai kepada pelanggan seperti jaringan pemasaran, kualitas pelayanan, reputasi organisasi, merek, hak cipta dan lisensi. 


\section{Strategi Bersaing Keunggulan Biaya (Cost Leaderships)}

Strategi dengan menerapkan biaya rendah dalam industrinya. Perusahaan memiliki cakupan yang luas dan melayani banyak segmen industri, dan bahkan mungkin beroperasi di dalam industri-industri terkait, luas perusahaan seringkali penting bagi keunggulan biayanya. Sumber keunggulan biaya bervariasi dan tergantung pada struktur industri. Sumber-sumber itu mungkin mencakup pengejaran skala ekonomis kepemilikan teknologi, akses istimewa ke bahan mentah dan faktor-faktor lain (Michael E. Porter, 2008). Penawaran produk/jasa dalam wilayah yang luas, Efisiensi operasi, Penawaran harga yang bersaing untuk produk/jasa, Peramalan dan Pertumbuhan pasar terhadap penjualan perusahaan.

\section{Kinerja Keuangan}

Kinerja sebagai sarana untuk mengevaluasi kemajuan yang dibuat selama periode waktu tertentu dan sebagai informasi untuk perencanaan masa depan dan pengambilan keputusan untuk perbaikan dan mengidentifikasi kekuatan dan kelemahan (Garengo et al, 2005) Profitabilitas, Ukuran Perusahaan dan Pertumbuhan (Growth)

\section{Uji Hipotesis}

Data merupakan penggambaran variabelvariabel yang akan diteliti dan berfungsi sebagai alat pembuktian hipotesis, serta menentukan hasil penelitian dan harus memenuhi dua persyaratan, yaitu unsur validitas dan unsur reliabilitas. Proses analisis data dilakukan melalui beberapa tahapan, mulai dari pengumpulan data, pemeriksaan dan verifikasi data lapangan, pengolahan data sampai kepada analisis data. Pengolahan data ini sendiri dimulai dengan pengkodean kuesioner, mentabulasikan, mengolahnya ke dalam software yang sudah disiapkan sampai interpretasi data.

Penelitian ini menggunakan alat analisis partial least square (PLS). PLS adalah salah satu metode statistika berbasis varian. Menurut Tenenhaus et al. (2005) PLS merupakan alat yang handal untuk menguji model prediksi karena memiliki keunggulan dibandingkan Lisrel dan Amos. Lebih lanjut PLS unggul karena: (1) Dapat digunakan untuk memprediksi model dengan landasan teori yang lemah, (2) Dapat digunakan pada data yang tidak memenuhi asumsi klasik (tidak berdistribusi normal, terdapat multikolinearitas, dan masalah autokorelasi), (3) Dapat digunakan untuk ukuran sampel kecil, dan (4) Dapat digunakan untuk konstruk formatif dan reflektif. Mutu pengukuran dan model, akan bisa dilihat melalui berbagai info statistik yang dihitung yaitu: Validitas konstruk (konvergen atau diskriminan), reliabilitas konstruk (cronbach's alpha atau composite reliability), dan signifikansi loading.

Untuk mengaplikasikan model PLS dalam penelitian ini menggunakan alat bantu software Smart PLS. Tahapan pemodelan dengan metode partial least square path modeling tidak jauh berbeda dengan SEM-Lisrel yaitu (1) Spesifikasi model, (2) Estimasi model, (3) Uji kecocokan model dan (4) Modifikasi/respesifikasi model dan (5) Pengujiaan hipotesis sebagi berikut:

1. Pengaruh sumber daya finansial dan aset tidak berwujud terhadap strategi bersaing

2. Pengaruh sumber daya finansial dan aset tidak berwujud terhadap kinerja keuangan di Lombok NTB

3. Pengaruh strategi bersaing terhadap kinerja keuangan

4. Pengaruh sumber daya finansial dan Aset tidak berwujud terhadap kinerja Keuangan melalui strategi bersaing UMKM di Lombok NTB

Selanjutnya menganalisis kelayakan usaha dilihat dari Net Present Value, Profitability Index, Payback Period dan Internal Rate Of Return pada sektor usaha PIJAR dan produk turunannya di Lombok NTB.

\section{HASIL DAN PEMBAHASAN}

\section{Sumber Daya Finansial}

1. Kapasitas untuk memperoleh informasi pasar keuangan (3,07): Program Pemerintah di Lombok NTB masih kurang efektif dalam mensosialisasikan untuk informasi pasar keuangan;

2. Kapasitas atau Kemampuan untuk Meningkatkan Modal (3,14): UMKM masih belum bankable dan feasible untuk bisa memperoleh pembiayaan perbankan;

3. Dimensi Akses Sumber Pembiayaan (3,36): Banyaknya lembaga keuangan yang memudahkan pelaku usaha untuk mengakses pembiayaan namun kurang sosialisasi;

4. Kemampuan untuk Memperoleh Sumber Pembiayaan dengan Biaya Rendah $(3,60)$ : Banyaknya lembaga keuangan memudahkan pelaku usaha untuk lebih selektif dalam tingkat pembiayaan yang rendah namun UMKM masih belum bankable dan feasible. 


\section{Aset Tidak Berwujud}

1. Dimensi Modal Inovasi (3,74): Kapasitas inovasi pelaku usaha PIJAR memiliki tingkat inovasi yang sedang hal ini dapat dilihat pada produk yang sudah jadi memiliki diversifikasi yang cukup banyak;

2. Dimensi Modal Manusia (4,16): Modal SDM untuk usaha pada komoditi PIJAR relatif lebih tinggi dibandingkan usaha pada sektor yang lain karena cukup banyak yang melakukan usaha sektor PIJAR;

3. Dimensi Modal Pelanggan $(3,66)$ : Komoditas unggulan Pijar yaitu komoditas peternakan sapi dan industri pengolahannya, budidaya jagung dan industri pengolahannya dan budidaya rumput laut dan industri pengolahannya memiliki kapasitas modal pelanggan yang tinggi.

\section{Strategi Bersaing}

1. Dimensi Penawaran Produk atau Jasa dalam Wilayah yang Luas Cukup Baik (3,73): komoditas produk unggulan Pijar di Lombok NTB mempunyai kapasitas yang sedang dalam hal kemampuan menawarkan produk atau jasa dalam wilayah yang cukup;

2. Efisiensi Operasi Cukup Baik (3,63): Untuk usaha PIJAR memiliki dimensi operasi yang tinggi hal ini menunjukkan bahwa komoditas tersebut memiliki tingkat efisien operasi tinggi;

3. Penawaran harga bersaing $(4,18)$ : komoditas unggulan Pijar memiliki kapasitas yang tinggi karena penjualan secara curah;

4. Kemampuan pelaku usaha meramalkan permintaan $(4,30)$ : Kemampuan meramalkan permintaan pelaku usaha relatif tinggi karena penjualan secara curah;

5. Pertumbuhan Pasar (3,75): Pertumbuhan pasar sedang karena penjualan produk Pijar masih pasar lokal;

6. Keunggulan Biaya $(3,92)$ : Keunggulan biaya relatif tinggi karena penjualan secara curah.

\section{Kinerja Keuangan}

1. Rata-Rata Tingkat Pengembalian Aset (Return on Asset) sebesar $40 \%$, hal ini dipandang sangat layak bagi perusahaan;

2. Rata rata nilai perusahaan sebesar 19,57 , hal ini mengindikasikan bahwa elemen perusahaan memiliki nilai yang sedang;

3. Rata-rata pertumbuhan penjualan sebesar $10 \%$.

4. Rata-Rata Tingkat Pengembalian Penjualan (Return on Sales) sebesar $27 \%$ jumlah tersebut cukup menguntungkan dari sisi kinerja keuangan.
Tabel 2. Model pengukuran (Outer Model)

\begin{tabular}{|c|c|c|c|}
\hline Variable & Indikator & oefisien & Probabilitas \\
\hline \multirow{6}{*}{$\begin{array}{l}\text { Modal Inovasi } \\
\text { (MI) }\end{array}$} & MI 1 & 0,534 & 0,072 \\
\hline & MI 2 & 0,956 & 0,005 \\
\hline & MI 3 & 0,875 & 0,001 \\
\hline & MI 4 & 0,908 & 0,001 \\
\hline & MI 5 & 0,590 & 0,070 \\
\hline & MI 6 & 0,088 & 0,052 \\
\hline \multirow{5}{*}{$\begin{array}{l}\text { Modal Manusia } \\
(\mathrm{MM})\end{array}$} & MM 1 & 0,843 & 0,009 \\
\hline & MM 2 & 0,305 & 0,239 \\
\hline & MM 3 & 0,939 & 0,000 \\
\hline & MM 4 & 0,309 & 0,163 \\
\hline & MM 5 & 0,427 & 0,175 \\
\hline \multirow{5}{*}{$\begin{array}{l}\text { Modal Pelanggan } \\
(\mathrm{MP})\end{array}$} & MP 1 & 0,517 & 0,138 \\
\hline & MP 2 & 0,519 & 0,235 \\
\hline & MP 3 & 0,613 & 0,072 \\
\hline & MP 4 & 0,713 & 0,015 \\
\hline & MP 5 & 0,314 & 0,140 \\
\hline \multirow{4}{*}{$\begin{array}{l}\text { Sumber Daya } \\
\text { Finansial } \\
(\mathrm{SDF})\end{array}$} & SDF 1 & 0,029 & 0,136 \\
\hline & SDF 2 & $-0,401$ & 0,008 \\
\hline & SDF 3 & $-0,605$ & 0,009 \\
\hline & SDF 4 & $-0,499$ & 0,007 \\
\hline \multirow{5}{*}{$\begin{array}{l}\text { Strategi Bersaing } \\
\text { (SB) }\end{array}$} & SB 1 & 0,697 & 0,008 \\
\hline & SB 2 & $-0,098$ & 0,408 \\
\hline & SB 3 & 0,431 & 0,083 \\
\hline & SB 4 & 0,488 & 0,024 \\
\hline & SB 5 & 0,732 & 0,012 \\
\hline \multirow{4}{*}{$\begin{array}{l}\text { Kinerja Keuangan } \\
(\mathrm{KK})\end{array}$} & KK 1 & $-0,034$ & 0,508 \\
\hline & KK 2 & 0,583 & 0,002 \\
\hline & KK 3 & $-0,014$ & 0,939 \\
\hline & KK 4 & $-0,145$ & 0,017 \\
\hline
\end{tabular}

Tabel 3. Composite reliability

\begin{tabular}{lrr}
\hline Variable & Koefisien & Probabilitas \\
\hline Kinerja Keuangan & 0,040 & 0,754 \\
Modal Inovasi & 0,845 & 0,000 \\
Modal Manusia & 0,724 & 0,002 \\
Modal Pelanggan & 0,673 & 0,002 \\
Strategi Bersaing & 0,588 & 0,008 \\
Sumber Daya Finansial & 0,403 & 0,065 \\
\hline
\end{tabular}

Tabel 4. Path coeficients

\begin{tabular}{llrr}
\hline \multicolumn{1}{c}{ Variable } & \multicolumn{1}{c}{ Indikator } & Koef. & Prob. \\
\hline \multirow{2}{*}{ Modal Inovasi } & Kinerja Keuangan & 0,370 & 0,026 \\
& Strategi Bersaing & 0,060 & 0,085 \\
\hline \multirow{2}{*}{ Modal Manusia } & Kinerja Keuangan & $-0,546$ & 0,124 \\
& Strategi Bersaing & 0,022 & 0,858 \\
\hline \multirow{2}{*}{ Modal Pelanggan } & Kinerja Keuangan & 0,168 & 0,350 \\
& Strategi Bersaing & 0,004 & 0,984 \\
\hline \multirow{2}{*}{ Sumber Daya } & Kinerja Keuangan & 0,270 & 0,623 \\
Finansial & Strategi Bersaing & $-0,482$ & 0,135 \\
\hline Strategi Bersaing & Kinerja Keuangan & 0,614 & 0,272 \\
\hline
\end{tabular}

Tabel 5. Hasil analisis kelayakan usaha

\begin{tabular}{lccc}
\hline \multicolumn{1}{c}{ Komoditas } & NPV (Rp.) & IRR (\%) & PI \\
\hline Sapi & $25.576 .029,-$ & 67,50 & 2,20 \\
Jagung & $64.538 .456,-$ & 65,52 & 2,05 \\
Rumput Laut & $57.242 .055,-$ & 75,53 & 2,66 \\
\hline
\end{tabular}




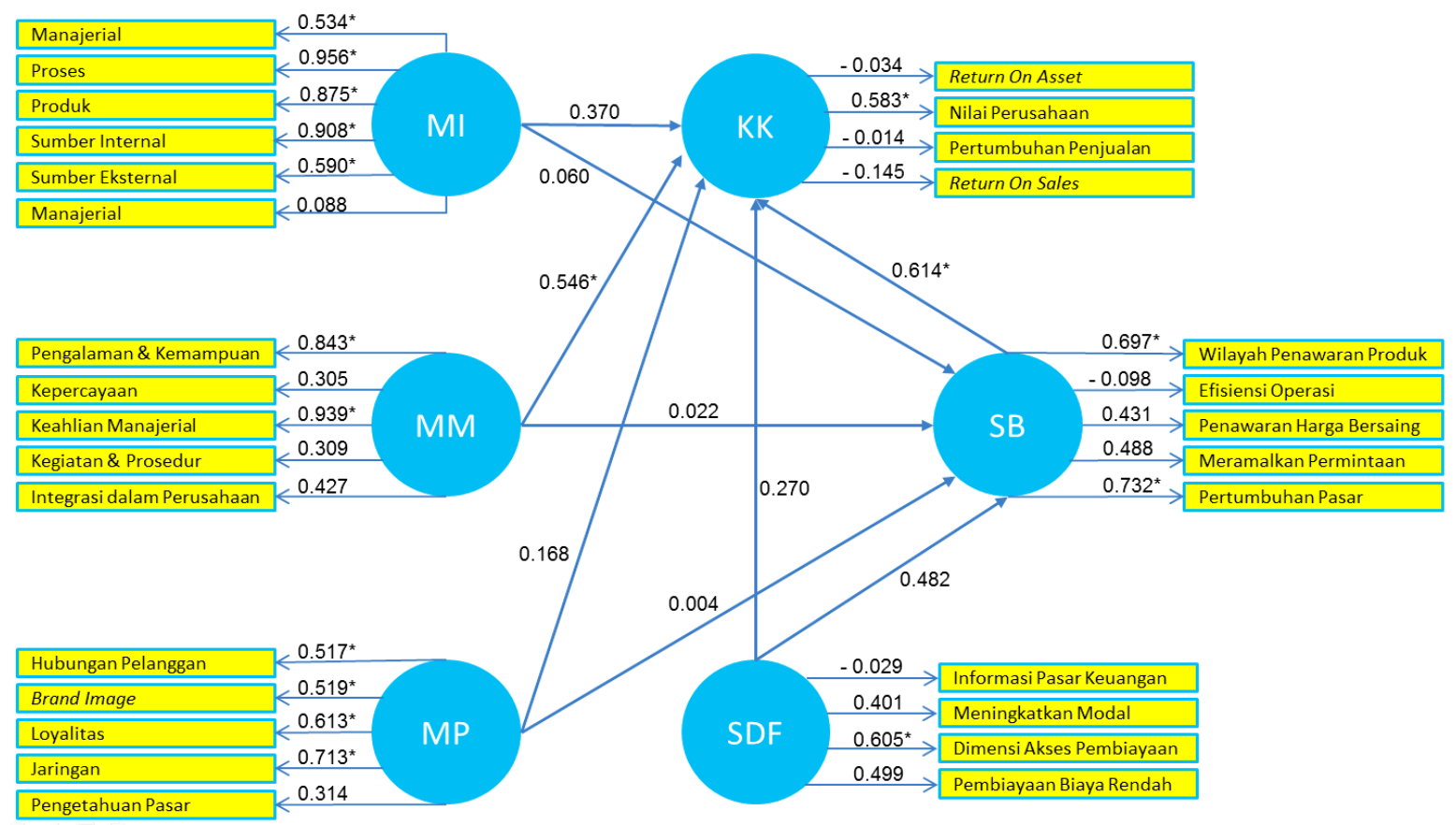

Gambar 1. Model struktural pengaruh antar peubah

Keterangan :

- Aset Tidak Berwujud terdiri dari Modal Inovasi (MI), Modal Manusia (MM), Modal Pelanggan (MP). Sumber Daya Finansial (SF), Kinerja Keuangan (KK) dan Strategi Bersaing (SB);

- Modal Inovasi tidak berpengaruh terhadap kinerja keuangan dan strategi bersaing;

- Modal Manusia berpengaruh terhadap kinerja keuangan namun tidak berpengaruh terhadap strategi bersaing;

- Modal Pelanggan tidak berpengaruh terhadap kinerja keuangan dan strategi bersaing;

- Sumber daya finansial tidak berpengaruh terhadap kinerja keuangan dan strategi bersaing;

- Strategi bersaing berpengaruh terhadap kinerja keuangan.

\section{Implikasi}

1. Secara teori hasil penelitian ini menambah informasi terhadap perkembangan ilmu berkenaan dengan ilmu manajemen keuangan, strategi bisnis. Kapasitas manajemen keuangan yang didukung dengan strategi bisnis yang tepat mampu meningkatkan kinerja keuangan usaha. Bukti empiric ini menjadi penguat teori terkait dengan faktor-faktor yang mempengaruhi kinerja keuangan;

2. Secara Praktis berimplikasi terhadap pentingnya pelaku usaha mengelola modal manusia, modal inovasi dan modal pelanggan untuk meningkatkan kinerja usaha. Sumber daya finansial merupakan salah satu faktor penting namun bukan yang paling utama dalam mempengaruhi kinerja keuangan. Strategi bersaing menjadi faktor yang perlu diperhatikan Karena mampu meningktakan kinerja keuangan namun perlu strategi yang tepat dalam menggunakan jenis strategi bersaing.

\section{KESIMPULAN}

1. Sumber daya finansial memiliki kapasitas yang cukup baik bagi pelaku usaha komoditas PIJAR, Asset Tidak Berwujud memiliki kapasitas yang sangat baik bagi pelaku usaha komoditas PIJAR, Strategi Bersaing Keunggulan Biaya cukup baik bagi pelaku usaha komoditas PIJAR dan Kinerja Keuangan cukup baik bagi pelaku usaha komoditas PIJAR.

2. Sumber daya finansial tidak berpengaruh terhadap kinerja keuangan dan strategi bersaing, serta strategi bersaing berpengaruh terhadap kinerja keuangan dengan demikian kapasitas Sumber daya Finansial yang cukup baik belum mampu berkontribusi terhadap Kinerja keuangan, dan Strategi Bersaing berpengaruh terhadap Kinerja Keuangan. Modal Inovasi tidak berpengaruh terhadap kinerja keuangan dan strategi bersaing, Modal Manusia berpengaruh terhadap kinerja keuangan namun tidak berpengaruh terhadap strategi bersaing serta Modal Pelanggan tidak berpengaruh terhadap kinerja keuangan dan strategi bersaing. 
3. Kelayakan usaha komoditas pijar dilihat dari NPV, PP, PI dan IRR mempunyai nilai kelayakan yang sangat baik.

\section{DAFTAR PUSTAKA}

[BPS] Badan Pusat Statistik. 20014. Statistik Indonesia 2014. Jakarta.

[BPS] Badan Pusat Statistik. 20015. Statistik Indonesia 2015. Jakarta.

[BPS] Badan Pusat Statistik. 20016. Statistik Indonesia 2016. Jakarta.

Camison, C. \& L.A. Villar. 2010. Effect of SMEs International Experience on Foreign Intensity and Economic Performance: the Mediating Role of Internatinally Exploitable Assets and Competitive Strategy, Journal of Small Business Management, 48(2). Pp 116151.

El-Hamidi, F. 2011. How Do Women Entrepreneurs Perform? Empirical Evidence from Egypt, AlmaLaurea, Working Papers 23 - ISSN 22399453, September, Inter University Consortium, Italia.

Frazier, B., L.S. Niehm. 2008. "FCS Students' attitudes and intentions toward entrepreneurial careers", Journal of Family and Consumer Sciences, April 2008, Vol 100 No. 2

Garengo, P., S. Biazzo, and B.S. Bittitci. 2005. Performance measurement systems in SMEs: A review for a research agenda, International Journal of Management Reviews, vol. 7, no. 1, p. 25.

Hadjimonalis, A. 2000. An Investig ion of Innovation Atecendent in Small Firms in the Contex of A Small Developing Country, Journal of R\&D Management, 30, 3, pp. 235245.
Hurst, E., A. Lusardi. 2004. Liquidity Constraints, Household Wealth, and Entrepreneurship, Journal of Political Economy. 2004. vol 112, no.2.

Kementerian Koperasi dan UKM. 2014. Data Statistik Perkoperasian 2014. Jakarta.

Kementerian Koperasi dan UKM. 2008. Laporan Penelitian Decision Support System Kelayakan Ekonomi dan Finansial UKM, Jakarta.

Kementerian Koperasi dan UKM. 2010. Laporan Kegiatan Oktober 2009-Desember 2010, Jakarta

Kotler, P. 2004. Manajemen Pemasaran. Jakarta : Prenhalindo.

Lengnick-Hall, M.L., A. Cynthia. 2003. Human Resource management in the knowledge economy, Berrett-Koehler Publisher, inc. San Francisco.

Marcus, A.A. 2011. Management Strategy: Achieving Sustained Competitive Advantage, McGraw-Hill international Edition, New York, Amerika.

Porter, M.E. 2008. Competitive Advantage, Terjemahan, Karisma Publishing Group.

Storey, D. 1994. New firm growth and bank financing. Small Business Economics, 6(2), 139-150.

Prakosa, B. 2005. Pengaruh Orientasi Pasar, Inovasi dan Orientasi Pembelajaran terhadap Kinerja Perusahaan untuk Mencapai Keunggulan Bersaing (Studi Empiris Pada Industri Manufaktur Di Semarang), Journal Studi Manajemen \& Organisasi, Vol. 2 No.1.

Umar, H.. Studi Kelayakan Bisnis. 2003. Teknik menganalisis Kelayakan rencana Bisnis Secara Komprehensif. Ed ke-2. Jakarta: Gramedia Pustaka Utama. 